\title{
Working with faculty to build collections
}

\author{
By Paul O. Jenkins
}

\section{Reach out and touch someone}

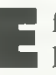
ffective collection development in the college library naturally starts with a thorough knowledge of the curriculum. Equally important, however, is a good working relationship with your coselectors, the faculty. Too often this relationship is strained and breeds misunderstanding or even resentment when harmony and cooperation are desired. To win the hearts-and perhaps the respect and trust - of faculty members, it's often helpful to court them by employing one or more of the strategies described below.

- Put together a bibliography of recent faculty publications. It's good for campus morale and can be shared with administrators. In order not to alienate those faculty who have yet to publish anything, include research interests as part of the bibliography. Update the list every three years or so.

\section{June 2 deadline for summer classified ads}

For those of you who will be placing classified ads over the summer, this is a reminder that the News publishes a combined July/August issue at the beginning of July and does not publish again until early September. If you have a position to advertise before September, the deadline is June 2 for the July/August issue. Late ads will be accepted on a space-available basis until June 14. To place an ad call Jack Helbig at (312) 280-2513; fax: (312) 280-7663; e-mail: jack.helhig@ala.org.
- Compile a "Faculty Recommends" reading list. Ask faculty members to list five titles they think every student should have read by graduation. Publish the list in-house and distribute free copies to everyone who participated. The publication serves as a real catalyst for improved communication among participants and nonparticipants alike.

- Pursue a rigorous program of SDI (selective dissemination of information) for faculty, based on the authors or interests identified by the two publications described above. Such a program might include a title update service wherein faculty are given quarterly updates of book titles published by specified authors or on specified topics. Print lists from CD-ROM proclucts such as BIPplus or $13 T$ Link.

- Set up a system by which faculty are informed whenever titles they've recommended have arrived and been cataloged. Send them an extra copy of a title's main entry card, or use your automated system to generate notifications that include full bibliographic information.

- Get out of the library and meet faculty on their turf. Serve on campus committees with them whenever possible. Eat lunch with them in the dining hall. Stop by the faculty mailroom to deliver memos and such. Attend faculty meetings whenever possible and make your voice heard at them. Lobby the administration to include you as an ex-officio member of the curriculum and other appropriate committees.

Using these and other ways to keep up good relations with faculty members can lead to an enhanced collection development program at your library.

Paul O. Jenkins is bead of collection development at the College of Mount St. Joseph in Cincinnati; e-mail:jenkins@clcunix.m.j.edu 
